\title{
KARAKTERISTIK DAN MOTIVASI WISATAWAN DALAM VOLUNTOURISM DI KABUPATEN GIANYAR (Studi Kasus Pada Yayasan Widya Guna Desa Bedulu dan Yayasan Bumi Sehat Desa Nyuh Kuning)
}

\author{
Irena Hersi Kristanti \\ Ni Made Oka Karini \\ I Putu Sudana \\ Email : irenahersi@gmail.com \\ PS. S1 Industri Perjalanan Wisata \\ Fakultas Pariwisata UNUD
}

\begin{abstract}
ABSTRAK
Nowadays social motivation appears in various forms of tourism activities, one of them is the presence of voluntourism activities in a foundation or village where tourist activity could bring sustainable positive impact for nature and local communities. In this study, the author is interested to collect the data about the characteristics and motivations of volunteer tourists on voluntourism in Widya Guna Foundation, Bedulu Village and Bumi Sehat Foundation, Nyuh Kuning Village, Gianyar Regency, Bali. The purpose of this study is to determine how the characteristics and motivations of volunteer tourists in both foundation in order to inspire other tourists in a choice of responsible tourism.

Methods of data collection which been used were observation, questionnaire, interview, and literature study. The results obtained by the data collection are that the characteristics of the volunteer tourists are divided into trip descriptor and tourist descriptor. Based on those descriptors, the volunteer tourists of Widya Guna and Bumi Sehat foundations are classified as discoverers, educators, and learners, befrienders, and investors. Motivations of volunteer tourists are divided into intrinsic motivations and extrinsic motivations. Intrinsically, their motivations are fulfilling a dream, personal growth, and professional development. While extrinsically are the attraction of travel or adventure places around the foundations, cultural exchange/learning, and a chance of broadening horizons. Recommended to governments, local communities, the inhabitants of the foundation, and the volunteer tourists to carry out their respective roles well and comply with the existing regulations in order to create the good impact of voluntourism activities for all parties concerned.
\end{abstract}

Keywords : Characteristic, Motivation, Tourist, Volunteer, Voluntourism.

\section{PENDAHULUAN}

Selama lima tahun terakhir, tingkat kunjungan wisatawan mancanegara ke Pulau Bali selalu mengalami peningkatan. Hal tersebut tidak hanya disebabkan oleh minat wisatawan mancanegara untuk menikmati keindahan alam dan mempelajari kebudayaan saja, namun ada motivasi lain yang mendorong mereka untuk berkunjung yaitu motivasi untuk berinteraksi dan ikut terlibat dalam kegiatan sehari-hari dengan masyarakat lokal yang membawa dampak positif bagi kedua belah pihak.

Motivasi tersebut merupakan bagian dari pariwisata alternatif, dimana terdapat nilai-nilai alam, sosial, dan masyarakat yang memungkinkan terjadinya interaksi positif dari wisatawan dan masyarakat lokal. Menurut PBB, pariwisata merupakan salah satu sector yang memberikan kontribusi positif untuk mewujudkan Millenium Development Goal's karena kemampuannya untuk menghasilkan pendapatan, mempengaruhi keseimbangan yang menguntungkan dari perdagangan, bermanfaat bagi masyarakat miskin dan menciptakan lapangan kerja.

Untuk mewujudkan hal tersebut, dibutuhkan praktek pembangunan berkelanjutan dan manajemen yang baik antara pemerintah, masyarakat lokal, dan pihak swasta. UNWTO mendukung pembangunan berkelanjutan tersebut dengan wujud pariwisata berkelanjutan untuk pengentasan kemiskinan melalui konsep volunteer TedQual Progam. Salah satu bentuk dari sustainable tourism adalah kegiatan voluntourism di suatu yayasan atau desa dimana 
aktivitas wisatawan dapat membawa dampak positif bagi masyarakat lokal. Wujud dari dampak positif tersebut adalah wisatawan volunteer datang membantu warga untuk meningkatkan ilmu pengetahuan dan keterampilan, berkontribusi untuk meningkatkan kualitas kesehatan warga, menambah pemasukan yayasan atau desa, dan memberikan motivasi bagi masyarakat lokal untuk membangun yayasan atau desa menjadi lebih baik.

Menurut PBB, konsep voluntary sudah ada sejak tahun 1970. Pastran (2014:47-51) menambahkan bahwa voluntourism itu sendiri sebenarnya sudah diperkenalkan pada dunia sejak tahun 1980 dan telah dilaksanakan di beberapa negara seperti Selandia Baru, Meksiko, Kanada dan di Benua Eropa. Dalam jurnal tersebut menyebutkan beberapa studi kasus, salah satunya mengenai voluntourism organization yang ada di Kanada yaitu Hero Canada dan Intercodia Canada. Kedua organisasi ini memfasilitasi wisatawan yang hendak bergabung dalam kegiatan voluntourism ke Amerika Latin, Afrika, dan beberapa negara kecil di Eropa Timur.

Di Indonesia sendiri telah didirikan banyak yayasan sosial yang menjadi tempat tujuan kegiatan voluntary, salah satunya adalah YPAC Nusa Dua, Bali. YPAC adalah yayasan yang bergerak dibidang pendidikan untuk anak dengan keterbelakangan mental dan kekurangan fisik. Bantuan yang diterima oleh yayasan tersebut selain dalam bentuk donasi, juga dalam bentuk tenaga pengajar yang diberikan oleh volunteer yang mayoritas berasal dari dalam negeri.

Selain YPAC, terdapat yayasan sosial lain yang cakupannya lebih luas atau internasional, yaitu Yayasan Widya Guna dan Yayasan Bumi Sehat yang keduanya terletak di Kabupaten Gianyar dan terdaftar secara resmi sesuai perundang-undangan yang berlaku. Kedua yayasan tersebut mengalami peningkatan jumlah kunjungan selama tiga tahun terakhir. Bantuan tenaga sukarela yang diperoleh seluruhnya berasal dari volunteer asal mancanegara. Selain tenaga sukarela, mereka juga memberikan bantuan berupa donasi atau sponsorship.

Berdasarkan latarbelakang tersebut, akan dibahas lebih lanjut mengenai bagaimana karakteristik dan motivasi wisatawan yang berkunjung ke Yayasan Widya Guna Desa Bedulu dan Yayasan Bumi Sehat Desa Nyuh Kuning Kabupaten Gianyar sebagai volunteer, mengingat dampak yang ditimbulkan sangat positif bagi masyarakat lokal dan wisatawan itu sendiri, serta mampu menjalin kerjasama yang baik antar negara dan memberikan teladan bagi wisatawan lain dalam pilihan berwisata yang bertanggungjawab.

\section{METODE PENELITIAN}

Lokasi penelitian berada di dua yayasan sosial, yaitu di Yayasan Widya Guna, Jalan Yeh Pulu, Banjar Batulumbang, Desa Bedulu, dan di Yayasan Bumi Sehat Desa Nyuh Kuning, Ubud, Kabupaten Gianyar. Variabel dan indikator untuk membatasi serta memperjelas permasalahan dalam penelitian ini yang pertama adalah karakteristik wisatawan secara trip descriptor atau gambaran mengenai perjalanannya, dan secara tourist descriptor atau gambaran mengenai diri wisatawan itu sendiri. Selain itu, wisatawan volunteer akan diklasifikasikan berdasarkan tipologi relawan.

Variabel selanjutnya adalah motivasi bagi wisatawan volunteer yang digolongkan secara intrinsik, yaitu dorongan yang berasal dari diri wisatawan, dan secara ekstrinsik, yaitu dorongan yang berasal dari luar atau lingkungan sekitar yang mempengaruhi wisatawan.

Jenis data yang digunakan adalah data kualitatif dan kuantitatif. Sumber data terdiri dari data primer dan data sekunder. Teknik pengumpulan data yang digunakan adalah observasi di kedua lokasi penelitian, menyebarkan kuesioner kepada seluruh voluntourists, mengadakan wawancara dengan pengelola kedua yayasan dan seluruh voluntourists, dan studi kepustakaan mengenai konsep yang terkait. Teknik penentuan informan menggunakan purposive sampling yaitu teknik pengambilan sampel dimana sampel dianggap paling tahu tentang apa yang diharapkan (Sugiyono, 2014:218). Dalam penelitian ini informan yang dimaksud adalah pengelola kedua yayasan.

Teknik penentuan sampel menggunakan Teknik Sensus, yaitu cara penentuan jumlah sampel dimana seluruh elemen populasi diselidiki satu persatu (Supranto, 2000:22). Dalam penelitian ini sampel yang dimaksud adalah seluruh voluntourists di kedua yayasan. Data yang terkumpul akan dianalisis dengan Teknik Analisis Deskriptif Kualitatif (Sugiyono, 2014:246-252), dengan aktivitas meliputi data reduction, data display, dan conclusion drawing.

\section{HASIL DAN PEMBAHASAN}

Yayasan Widya Guna adalah yayasan yang bergerak dibawah naungan Proyek WINS dari Belanda sebagai wadah bagi anak yatim piatu dan kekurangan atau kelumpuhan fisik dan mental untuk mereka menikmati hidup dan belajar serta berkarya. Pada Februari 2011, yayasan ini resmi terdaftar di Dinas Sosial Provinsi Bali. Program yang dijalankan oleh yayasan ini adalah program penyantunan anak, program pendidikan, dan program lainnya untuk mendukung pendanaan operasional yayasan. 
Yayasan Bumi Sehat pertama kali didirikan pada tahun 1995 sebagai non-profit organization di Indonesia, kemudian pada tahun 2005 yayasan ini telah diresmikan sesuai Undang-Undang. Yayasan ini bergerak dibidang kesehatan untuk para ibu, baik dalam kondisi hamil hingga pasca melahirkan. Serta bergerak dibidang pemenuhan kesehatan dan pendidikan bagi anak-anak, beasiswa kebidanan, serta perawatan kesehatan untuk wanita, dan lansia.

Jumlah seluruh wisatawan volunteer di kedua yayasan tersebut adalah 16 orang. Adapun hasil yang diperoleh dari keenambelas wisatawan volunteer melalui penyebaran kuesioner dan wawancara adalah sebagai berikut :

Tabel 1 Karakteristik Perjalanan Wisatawan Dalam Voluntourism Secara Trip Descriptor

\begin{tabular}{|c|c|c|c|c|}
\hline \multirow{2}{*}{ Pernyataan } & \multicolumn{2}{|c|}{$\begin{array}{c}\text { Yayasan } \\
\text { Widya Guna }\end{array}$} & \multicolumn{2}{|c|}{$\begin{array}{c}\text { Yayasan Bumi } \\
\text { Sehat }\end{array}$} \\
\hline & (orang) & $(\%)$ & (orang) & $(\%)$ \\
\hline $\begin{array}{l}\text { Tujuan Datang ke } \\
\text { Bali : } \\
\text { a. Visiting family } \\
\text { b. Voluntary } \\
\text { c. Vacation \& } \\
\text { Voluntary }\end{array}$ & $\begin{array}{l}- \\
3 \\
7\end{array}$ & $\begin{array}{c}- \\
30 \\
70\end{array}$ & $\begin{array}{l}3 \\
- \\
6\end{array}$ & $\begin{array}{c}50 \\
- \\
100\end{array}$ \\
\hline $\begin{array}{l}\text { Lama Tinggal di } \\
\text { Bali : } \\
\text { a. } 4-7 \text { hari } \\
\text { b. } 8-28 \text { hari } \\
\text { c. } 29-91 \text { hari } \\
\text { d. } 92-365 \text { hari }\end{array}$ & $\begin{array}{l}1 \\
8 \\
1 \\
- \\
\end{array}$ & $\begin{array}{c}10 \\
80 \\
10 \\
- \\
\end{array}$ & $\begin{array}{l}- \\
- \\
3 \\
3 \\
\end{array}$ & $\begin{array}{c}- \\
- \\
50 \\
50 \\
\end{array}$ \\
\hline $\begin{array}{l}\text { Waktu } \\
\text { Pelaksanaan } \\
\text { Perjalanan : } \\
\text { a. Hari libur } \\
\text { b. Hari kerja }\end{array}$ & $\begin{array}{l}9 \\
1\end{array}$ & $\begin{array}{l}90 \\
10\end{array}$ & $\begin{array}{l}3 \\
3 \\
\end{array}$ & $\begin{array}{l}50 \\
50\end{array}$ \\
\hline $\begin{array}{l}\text { Jalur Transportasi: } \\
\text { a. Udara }\end{array}$ & 10 & 100 & 6 & 100 \\
\hline $\begin{array}{l}\text { Moda } \\
\text { Transportasi: } \\
\text { a. Kendaraan } \\
\text { pribadi } \\
\text { b. Kendaraan sewa } \\
\text { c. Kendaraan } \\
\text { umum }\end{array}$ & $\begin{array}{l}6 \\
-\end{array}$ & $\begin{array}{l}40 \\
60 \\
-\end{array}$ & $\begin{array}{l}- \\
4 \\
2\end{array}$ & $\begin{array}{c}- \\
66,67 \\
33,33\end{array}$ \\
\hline $\begin{array}{l}\text { Periodisitas } \\
\text { Kunjungan : } \\
\text { a. Kunjungan } \\
\text { pertama kali } \\
\text { b. Kunjungan ke 2-- } \\
5 \text { kali } \\
\text { c. Rutin }\end{array}$ & 2 & $\begin{array}{l}80 \\
20 \\
-\end{array}$ & $\begin{array}{l}2 \\
3 \\
1\end{array}$ & $\begin{array}{c}33,33 \\
50 \\
16,67\end{array}$ \\
\hline $\begin{array}{l}\text { Pengorganisasian } \\
\text { Perjalanan : }\end{array}$ & & & & \\
\hline
\end{tabular}

\begin{tabular}{|c|c|c|c|c|}
\hline $\begin{array}{l}\text { a. Paket tur } \\
\text { b. Sendiri } \\
\text { c. Organisasi } \\
\text { Volunteers }\end{array}$ & $\begin{array}{l}1 \\
7 \\
2\end{array}$ & $\begin{array}{l}10 \\
70 \\
20\end{array}$ & $\begin{array}{l}- \\
5 \\
1\end{array}$ & $\begin{array}{c}- \\
83,33 \\
16,67\end{array}$ \\
\hline $\begin{array}{l}\text { Teman Perjalanan: } \\
\text { a. Sendiri } \\
\text { b. Kolega/teman } \\
\text { c. Keluarga }\end{array}$ & $\begin{array}{l}4 \\
6 \\
- \\
\end{array}$ & $\begin{array}{c}40 \\
60 \\
-\end{array}$ & $\overline{1}$ & $\begin{array}{c}83,33 \\
- \\
16,67\end{array}$ \\
\hline $\begin{array}{l}\text { DTW yang } \\
\text { Dikunjungi : } \\
\text { a. Nusa } \\
\text { Lembongan } \\
\text { b. Tegalalang } \\
\text { c. Monkey Forest } \\
\text { d. Tampak Siring } \\
\text { e. Pura Gunng } \\
\text { Kawi }\end{array}$ & $\begin{array}{l}4 \\
5 \\
7 \\
5\end{array}$ & $\begin{array}{l}40 \\
50 \\
70 \\
50\end{array}$ & $\begin{array}{l}6 \\
6 \\
6 \\
6\end{array}$ & $\begin{array}{l}100 \\
100 \\
100 \\
100\end{array}$ \\
\hline $\begin{array}{l}\text { Rata-rata } \\
\text { Pengeluaran/hari } \\
\text { (Rp) : } \\
\text { a. } \leq 200.000 \\
\text { b. } 201.000-400.000 \\
\text { c. } 401.000-600.000 \\
\text { d. } 601.000-800.000\end{array}$ & $\begin{array}{l}2 \\
4 \\
3 \\
1\end{array}$ & $\begin{array}{l}20 \\
40 \\
30 \\
10\end{array}$ & $\begin{array}{l}1 \\
5 \\
- \\
-\end{array}$ & $\begin{array}{c}16,67 \\
83,33 \\
- \\
-\end{array}$ \\
\hline $\begin{array}{l}\text { Sumber : Yayasan Widya } G \\
\text { Secara trip } d \\
\text { kedua yayasan data } \\
\text { yaitu vacation \& } \\
\text { yang bervariasi yait } \\
\text { yang berada di Yay } \\
91 \text { hari hingga } 92-3 \\
\text { di Yayasan Bun } \\
\text { dilaksanakan saat } \\
\text { sebagian wisatawan } \\
\text { bagi mereka memb } \\
\text { adalah bagian } \\
\text { transportasi yang } \\
\text { Mayoritas wisata } \\
\text { kendaraan sewa seb } \\
\text { Bali, karena hal ter } \\
\text { menjangkau berbag }\end{array}$ & $\begin{array}{l}\text { n } \mathrm{W} \\
\text { hari } \\
\mathrm{Se} \\
\text { lib } \\
\mathrm{Ya} \\
\text { tu } \mathrm{s} \\
\mathrm{p} \\
\text { guna } \\
\mathrm{n}\end{array}$ & $\begin{array}{r}\mathrm{Gu} \\
\mathrm{km} \\
\mathrm{pe} \\
\mathrm{aup} \\
\mathrm{n} \mathrm{B} \\
\mathrm{ad} \\
\mathrm{aan} \\
\mathrm{ad} \\
\text { atee }\end{array}$ & $\begin{array}{l}\text { ya } \\
\text { han }\end{array}$ & $\begin{array}{l}\text { eer di } \\
\text { utama } \\
\text { inggal } \\
\text { ereka } \\
\text { na 29- } \\
\text { berada } \\
\text { ereka } \\
\text { a bagi } \\
\text { karena } \\
\text { ehatan } \\
\text { Jalur } \\
\text { udara. } \\
\text { nakan } \\
\text { ma di } \\
\text { untuk }\end{array}$ \\
\hline
\end{tabular}

Kegiatan voluntourism ini merupakan kunjungan yang pertama bagi mayoritas wisatawan volunteer di Yayasan Widya Guna, dan merupakan kunjungan ulang bagi wisatawan volunteer di Yayasan Bumi Sehat. Perjalanan voluntourism dapat diatur melalui paket tur, diri sendiri, dan organisasi volunteer, mayoritas wisatawan mengatur perjalanannya sendiri karena mereka dapat menemukan yayasan sosial atau tempat yang menjadi sasaran mereka melalui website atau online research. Mayoritas wisatawan volunteer yang ada di Yayasan Widya Guna datang ke Bali bersama teman, sedangkan untuk mereka yang berada di Yayasan Bumi Sehat lebih memilih untuk melakukan perjalanannya sendirian, karena mereka sudah pernah 
berkunjung ke Bali dan merasa cukup percaya diri dalam kunjungannya kali ini.

DTW yang dikunjungi selama di Bali sangat bervariasi, adapaun DTW dengan potensi alam yang menjadi favorit mereka adalah Nusa Lembongan, Monkey Forest, dan Tegalalang. Sedangkan DTW dengan potensi budaya yang menjadi favorit mereka adalah Tampak Siring dan Pura Gunung Kawi. DTW alam maupun budaya tersebut letaknya tidak terlalu jauh dari lokasi voluntary dan kegiatan yang dapat dilakukan disana sangat sesuai dengan karakter mereka. Rata-rata pengeluaran mayoritas wisatawan volunteer diluar biaya donasi ke yayasan. adalah sebesar Rp 201.000,- hingga Rp 400.000,- untuk memenuhi kebutuhan mereka sehari-hari selama berada di Bali.

Tabel 2 Karakteristik Wisatawan Dalam Voluntourism Secara Tourist Descriptor

\begin{tabular}{|c|c|c|c|c|}
\hline \multirow{2}{*}{ Pernyataan } & \multicolumn{2}{|c|}{$\begin{array}{c}\text { Yayasan Widya } \\
\text { Guna }\end{array}$} & \multicolumn{2}{|c|}{$\begin{array}{c}\text { Yayasan Bumi } \\
\text { Sehat }\end{array}$} \\
\hline & (orang) & $(\%)$ & (orang) & $(\%)$ \\
\hline $\begin{array}{l}\text { Jenis Kelamin : } \\
\text { a. Laki-laki } \\
\text { b. Perempuan }\end{array}$ & $\begin{array}{l}1 \\
9 \\
\end{array}$ & $\begin{array}{l}10 \\
90\end{array}$ & - & $\begin{array}{c}- \\
100\end{array}$ \\
\hline $\begin{array}{l}\text { Negara Asal : } \\
\text { a. Inggris } \\
\text { b. Belanda }\end{array}$ & $\begin{array}{l}3 \\
2\end{array}$ & $\begin{array}{l}30 \\
20\end{array}$ & $\begin{array}{l}2 \\
-\end{array}$ & $\begin{array}{c}33 \\
-\end{array}$ \\
\hline $\begin{array}{l}\text { Usia: } \\
\text { a. 15-24 tahun } \\
\text { b. } 25-44 \text { tahun }\end{array}$ & $\begin{array}{l}8 \\
2\end{array}$ & $\begin{array}{l}80 \\
20\end{array}$ & $\begin{array}{l}3 \\
3\end{array}$ & $\begin{array}{l}50 \\
50\end{array}$ \\
\hline $\begin{array}{l}\text { Pekerjaan : } \\
\text { a. Pelajar } \\
\text { b. Profesional } \\
\text { c. Pengusaha } \\
\end{array}$ & $\begin{array}{l}7 \\
2 \\
1 \\
\end{array}$ & $\begin{array}{l}70 \\
20 \\
10 \\
\end{array}$ & $\begin{array}{l}3 \\
3 \\
- \\
\end{array}$ & $\begin{array}{r}50 \\
50 \\
- \\
\end{array}$ \\
\hline $\begin{array}{l}\text { Pendidikan } \\
\text { Terakhir: } \\
\text { a. SMA } \\
\text { b. S1 } \\
\text { c. S2/S3 }\end{array}$ & $\begin{array}{l}2 \\
7 \\
1\end{array}$ & $\begin{array}{l}20 \\
70 \\
10\end{array}$ & $\begin{array}{l}1 \\
2 \\
3\end{array}$ & $\begin{array}{c}16,67 \\
33,33 \\
50\end{array}$ \\
\hline $\begin{array}{l}\text { Status } \\
\text { Pernikahan: } \\
\text { a. Menikah } \\
\text { b. Lajang }\end{array}$ & $\begin{array}{l}1 \\
9 \\
\end{array}$ & $\begin{array}{l}10 \\
90\end{array}$ & $\overline{6}$ & $\begin{array}{c}- \\
100\end{array}$ \\
\hline $\begin{array}{l}\text { Aktivitas yang } \\
\text { Dilakukan : } \\
\text { a. Sighseeing \& } \\
\text { Volunteering } \\
\text { b. Religion \& } \\
\text { spiritual } \\
\text { c. Adventure } \\
\text { d. Night Life } \\
\text { e. Shopping \& } \\
\text { Wellness }\end{array}$ & $\begin{array}{l}6 \\
8 \\
6\end{array}$ & $\begin{array}{l}60 \\
80 \\
60\end{array}$ & $\begin{array}{l}6 \\
3 \\
4\end{array}$ & $\begin{array}{c}100 \\
66,67 \\
100 \\
50 \\
66,67\end{array}$ \\
\hline
\end{tabular}

\begin{tabular}{|c|c|c|c|c|}
\hline $\begin{array}{l}\text { Tempat } \\
\text { Menginap : } \\
\text { a. Homestay / } \\
\text { Volunteer's } \\
\text { Asram }\end{array}$ & 10 & 100 & 6 & 100 \\
\hline
\end{tabular}

Sumber : Yayasan Widya Guna dan Yayasan Bumi Sehat, 2015.

Secara tourist descriptor, wisatawan volunteer yang ada di Yayasan Widya Guna dan Yayasan Bumi Sehat didominasi oleh wisatawan perempuan, karena secara umum apabila dibandingkan dengan laki-laki, perempuan memiliki kepekaan dan kelemahlembutan dalam menghadapi anak-anak. Khusus untuk wisatawan volunteer yang ada di Yayasan Bumi Sehat seluruhnya dalah perempuan, kerena yayasan ini bergerak dibidang kesehatan untuk para wanita sebagai program utamanya.

Rentang usia wisatawan yang mendominasi adalah antara 15-24 tahun dengan status sebagai pelajar yang sedang atau telah menempuh pendidikan di Universitas. Dengan rentang usia tersebut, mayoritas wisatawan volunteer berstatus belum menikah, mereka merasa bahwa hal tersebut adalah status yang tepat untuk melaksanakan kegiatan voluntourism karena membutuhkan banyak waktu dan tenaga serta konsentrasi yang penuh. Kegiatan yang mereka lakukan selama berada di Bali adalah sightseeing, volunteering, dan religion/spiritual, baik di likasi voluntary dan di DTW alam serta budaya yang telah mereka kunjungi. Selama kegiatan voluntourism tersebut, mereka menginap di homestay milik pengelola yayasan bagi wisatawan yang ada di Yayasan Widya Guna atau di volunteer's asram bagi wisatawan yang ada di Yayasan Bumi Sehat.

Tabel 3 Karakteristik Wisatawan Dalam Voluntourism Menurut Tipologi

\begin{tabular}{|c|c|c|c|c|}
\hline \multirow{2}{*}{ Pernyataan } & \multicolumn{2}{|c|}{$\begin{array}{c}\text { Yayasan } \\
\text { Widya Guna }\end{array}$} & \multicolumn{2}{|c|}{$\begin{array}{c}\text { Yayasan Bumi } \\
\text { Sehat }\end{array}$} \\
\hline & (orang) & $(\%)$ & (orang) & $(\%)$ \\
\hline $\begin{array}{l}\text { a. Discoverers, } \\
\text { Educators, } \\
\text { Learners, } \\
\text { Befrienders, } \\
\text { Investors }\end{array}$ & 10 & 100 & 6 & 100 \\
\hline $\begin{array}{l}\text { b. Leisure's } \\
\text { seekers }\end{array}$ & 7 & 70 & 5 & 83,33 \\
\hline c. Adventurers & 6 & 60 & 6 & 100 \\
\hline d. Activists & 3 & 30 & 6 & 100 \\
\hline
\end{tabular}

Sumber : Yayasan Widya Guna dan Yayasan Bumi Sehat, 2015.

Menurut tipologi relawan, wisatawan volunteer di kedua yayasan tergolong sebagai discoverers, educators \& learners, befrienders, dan investors. Yaitu individu yang memiliki minat untuk menjelajahi, mempelajari, dan bergaul lebih intensif dari pada jenis wisatwan lainnya. 
Tabel 4 Motivasi Wisatawan Dalam Voluntourism Secara Intrinsik dan Ekstrinsik

\begin{tabular}{|c|c|c|c|c|}
\hline \multirow{2}{*}{ Pernyataan } & \multicolumn{2}{|c|}{$\begin{array}{c}\text { Yayasan } \\
\text { Widya Guna }\end{array}$} & \multicolumn{2}{|c|}{$\begin{array}{c}\text { Yayasan Bumi } \\
\text { Sehat }\end{array}$} \\
\hline & (orang) & $(\%)$ & (orang) & $(\%)$ \\
\hline $\begin{array}{l}\text { a. Fulfilling a } \\
\text { dream, personal } \\
\text { growth, } \\
\text { professional } \\
\text { development } \\
\text { b. Travel/ } \\
\text { adventure, cultural } \\
\text { exchange/ } \\
\text { learning, } \\
\text { broadening } \\
\text { horizons }\end{array}$ & 10 & 100 & 6 & 100 \\
\hline
\end{tabular}

Motivasi wisatawan dalam voluntourism secara intrinsik adalah untuk fulfilling a dream, atau mewujudkan mimpi yang mereka miliki sejak dulu yaitu untuk membantu sesama, personal growth, atau mengembangkan kepribadian mereka kearah yang lebih baik yaitu pribadi yang lebih bersyukur dan menyadari potensi diri, serta professional development, atau pengembangan profesi yaitu membekali diri untuk persiapan jenjang karir dan masa depan mereka. Sedangkan secara ekstrinsik, motivasi wisatawan volunteer adalah karena adanya pengaruh dari tempat tujuan volunteering untuk melakukan kegiatan travel/adventure, adanya kesempatan untuk cultural exchange/learning atau mempelajari kebudayaan dan bahasa yang berbeda bersama warga lokal, dan adanya kesempatan untuk broadening horizons, atau mencari pengalaman yang akan didapat dari cakrawala yang berbeda, yaitu dengan cara melakukan voluntourism ke luar negeri atau abroad.

Dari keenambelas wisatawan volunteer yang berkunjung ke Yayasan Widya Guna maupun Yayasan Bumi Sehat, mayoritas menghabiskan waktu untuk kegiatan voluntourism diatas 1 minggu dan melaksanakannya pada saat hari libur, hal tersebut karena karakteristik perjalanan seorang wisatawan volunteer adalah membutuhkan waktu yang tidak singkat untuk menikmati dan memberikan kontribusi pada kegiatan ini, dimulai dari beradaptasi terhadap lingkungan alam dan sosial serta cara kerja di dalam sebuah organisasi warga lokal.

Selama berada di Bali, mereka memilih kendaraan sewa sebagai moda transportasi. Meskipun kunjungan kali ini adalah kunjungan yang pertama kali dan dilakukan sendirian, namun mereka senang dengan kesempatan untuk berpetualang menjelajahi daerah sekitar voluntary program sesuai keinginan dan minat mereka. Hal tersebut karena karakteristik perjalanan seorang wisatawan volunteer adalah membutuhkan ruang yang luas untuk menjelajahi destinasi voluntourism dan tidak bergantung pada orang lain.

Adapun Daerah Tujuan Wisata di Bali yang telah mereka kunjungi sangat beragam, yaitu terdiri dari DTW alam dan budaya. Dalam kunjungan mereka ke DTW tersebut, mereka menghabiskan biaya rata-rata $\mathrm{Rp} 201.000$,- hingga $\mathrm{Rp} 400.000$,- per hari, termasuk untuk biaya konsumsi dan kebutuhan pokok lainnya, namun belum termasuk biaya donasi untuk yayasan. Hal tersebut karena karakteristik perjalanan seorang wisatawan volunteer adalah lebih memilih mengalokasikan biaya liburannya untuk donasi dan pembangunan kegiatan voluntary dari pada untuk kesenangan pribadi.

Limabelas dari keenambelas wisatawan adalah perempuan, mayoritas dari mereka berasal dari Negara Inggris dengan usia muda atau dalam masa gap-year yang tentu saja masih bertatus belum menikah. Hal tersebut karena karakteristik seorang wisatwan volunteer adalah individu yang memiliki energi yang besar namun lemah lembut serta sabar, berasal dari negara maju, dimana perekonomiannya lebih mendukung, disertai dengan waktu luang yang cukup banyak, dan tidak terbeban dengan tanggungjawab lain, sehingga individu tersebut bisa memberikan waktu dan tenaganya secara totalitas dalam kegiatan voluntourism ini.

Aktivitas yang mereka lakukan selama berada di Bali selain sightseeing dan volunteering didominasi oleh aktivitas religion \& spiritual, dan adventure. Hal tersebut karena karakteristik seorang wisatawan volunteer adalah individu yang menyukai aktivitas yang memberikan ketenangan batin dan menggali diri lebih dalam lagi dengan aktivitas yang menantang dan unik. Selama berada di Bali, seluruh wisatwan volunteer menginap di penginapan yang disediakan oleh pengelola yayasan, karena hal tersebut sudah termasuk dalam voluntary program dan membuka kesempatan bagi mereka untuk dapat berinteraksi lebih intensif dengan warga lokal.

Berdasarkan pembahasan mengenai karakteristik wisatawan volunteer di kedua yayasan tersebut, secara tipologi relawan, mereka tergolong sebagai discoverers, educators \& learners, yaitu wisatawan volunteer yang ingin meningkatkan dan menyebarluaskan ilmu pengetahuan serta mengasah keterampilan, baik bagi masyarakat lokal maupun dirinya sendiri. Selain itu, mereka juga termasuk sebagai befrienders, yaitu wisatawan volunteer yang ingin bergaul dan belajar bersama masyarakat lokal untuk memperlebar akses bagi masyarakat lokal yang ingin berkreasi, dan sebagai investors, yaitu wisatawan volunteer yang memberikan bantuan kepada yayasan berupa donasi atau mengadakan 
penggalian dana untuk menambah pemasukan yayasan.

Motivasi dari seluruh wisatwan volunteer yang berkunjung ke kedua yayasan tersebut secara intrinsic adalah karena adanya keinginan untuk mengisi waktu luang mereka dengan kegiatan yang bermanfaat bagi diri sendiri dan sesama yang membutuhkan, yaitu untuk fulfilling a dream, personal growth, dan professional development. Secara ekstrinsik, atau yang berasal dari luar individu tersebut adalah karena adanya kesempatan di daerah tujuan voluntourism untuk melakukan kegiatan yang menantang dan unik atau kegiatan travel/adventure, kegiatan yang mampu membawa pembelajaran dan pertukaran budaya serta bahasa dengan warga lokal, yaitu cultural exchange/learning, dan kesempatan untuk broadening horizon, yaitu mendobrak batas-batas yang ada antara individu tersebut dengan dunia luar untuk memperluas wawasan dan persahabatan.

\section{SIMPULAN DAN SARAN}

Karakteristik mayoritas wisatawan dalam voluntourism di Yayasan Widya Guna dan Yayasan Bumi Sehat dapat dilihat secara trip descriptor atau gambaran mengenai perjalanannya, yaitu bahwa tujuan mereka datang ke Bali adalah untuk liburan sambil menjadi relawan, mereka mengatur perjalanannya sendiri dengan lama tinggal di Bali minimal selama 1 bulan, dan pengeluaran rata-rata per hari sebesar Rp 201.000,- hingga Rp 400.000,-. Secara tourist descriptor atau gambaran mengenai diri wisatawan, diketahui bahwa wisatawan yang mendominasi adalah wisatawan wanita asal Negara Inggris dengan usia 15-24 tahun. Dari kedua deskripsi tersebut, mayoritas wisatawan volunteer yang datang ke kedua yayasan tersebut tergolong sebagai wisatawan volunteer dengan tipe discoverers, educators, and learners, befrienders, dan investors.

Adapun motivasi wisatawan dalam voluntourism di Yayasan Widya Guna dan Yayasan Bumi Sehat terbagi menjadi motivasi intrinsik dan motivasi ekstrinsik. Secara intrinsik, motivasi dari mayoritas wisatawan volunteer adalah keinginan mereka untuk fulfilling a dream, personal growth, dan professional development. Secara ekstrinsik, motivasi dari mayoritas wisatawan volunteer adalah karena adanya kesempatan untuk melakukan aktivitas travel or adventure, cultural exchange or learning, dan broadening horizons.

Berdasarkan simpulan tersebut, saran yang dapat diberikan adalah pemerintah dan Badan Imigrasi sebaiknya lebih memberi kemudahan dalam hal perijinan bagi para wisatawan volunteer, agar kegiatan voluntourism ini dapat dilaksanakan tepat waktu dan tepat sasaran. Selanjutnya, perlu dilakukan penelitian yang lebih mendalam lagi mengenai persepsi masyarakat lokal terhadap terhadap kegiatan voluntourism dan dampak yang ditimbulkannya, agar bisa menentukan keberlanjutan dari kegiatan tersebut.

\section{DAFTAR PUSTAKA}

Pastran, Sasha Hanson, 2014, Volunteer Tourism : A Postcolonial Approach. In (Ed.) University of Saskatchewan Undergraduate Research Journal. Volume 1, Issue 1, (pp. 45-5).

Seaton, A.V. dan M.M. Bennett. 1996, The Marketing of Tourism Product : Concepts, Issues, and Cases. International Thomson Business Press, London.

Stebbins, R.A., \& M. Graham 2004, (Eds.) Volunteering as Leisure, Leisure as Volunteering - An International Assessment. Oxon, Wallingford, UK : CAB International.

Sugiyono, 2014, Metode Penelitian Kuantitatif, Kualitatif, dan R\&D. Bandung : Alfabeta.

Supranto, J., 2000, Statistik, Teori dan Aplikasi. Jakarta : Erlangga.

Söderman, N., and S. L. Snead, 2008, Opening the Gap: the Motivation of Gap Year Travelers to Volunteer in Latin America. In K.D. Lyons \& S. Wearing (Eds.) Journeys of Discovery in Volunteer Tourism. Wallingford, UK: CAB International. (pp. 118-129).

Wearing, S., 2008, The Volunteer's Journey Through Leisure into the Self. In S. Wearing \& K. Lyons (Eds.) Journeys of Discovery in Volunteer Tourism. Wallingford, UK : CAB International. (pp. 63-71).

Wearing, S., 2008, Volunteer Tourism as Alternative Tourism : Journeys Beyond Otherness. In S. Wearing \& K. Lyons (Eds.) Journeys of Discovery in Volunteer Tourism. Wallingford, UK : CAB International. (pp. 311).

William, R., and Valene L., 1992, Tourism Alternatives Potentials and Problems in The Development of Tourism. UK : Wiley \& Sons Ltd.

Internet :

Kunjungan Wisatawan Mancanegara Tahun 20102014:

http://bali.bps.go.id/tabel detail.php?ed $=611001 \& o$

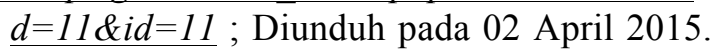

